\title{
Distribuição e contexto espacial de depressões fechadas na porção sul da serra do Caparaó (região de Espera Feliz, MG), como subsídio à compreensão da evo- lução regional do relevo.
}

\author{
Distribution and spatial context of closed depressions in the southern portion of the \\ Serra da Caparaó (Espera Feliz region, $M G$ ), as a subsidy to the understanding the \\ regional evolution of the relief.
}

Erick de Oliveira Faria
Geógrafo, mestrando em Geografia pela PUC-Minas, Bolsista do CNPq - Brasil
erickolifaria@gmail.com

\begin{abstract}
Resumo
Depressões fechadas são feições de formato arredondado que apresentam ausência de um canal de saída de fluxos d'agua superficiais. Sua presença já foi identificada em diversos contextos paisagísticos com diferentes explicações no que refere a sua gênese e seu papel na evolução da paisagem. O local de estudo do presente trabalho situa-se nas proximidades do município de Espera Feliz-MG, localizado na porção sul da Serra do Caparaó, que tem como característica em seu cenário paisagístico a presença destas feições. Assim sendo, este trabalho objetivou integrar técnicas de sensoriamento remoto e de processamento e análise espacial, integrando variáveis físicas como, pedologia, hidrografia, hipsometria, declividade e litologia buscando avaliar padrões de dispersão e concentração, na paisagem do local de estudo. Os resultados mostraram que há um padrão topográfico / geomorfológico de ocorrência para as 108 feições identificadas, isto é, um compartimento intermediário da paisagem formado por colinas e morros policonvexos, mais precisamente nas suas vertentes. No conjunto, acredita-se que se tratem de cicatrizes de movimentos de massa ou outras formas de erosão, revelando uma intima associação entre pedogênese e morfogênese na paisagem regional.
\end{abstract}

Palavras-chave: Sensoriamento Remoto; Depressões Fechadas; Evolução da Paisagem.

\begin{abstract}
Closed depressions are rounded-shaped features that exhibit no outlet channel for surface water flows. Its presence has already been identified in several landscape contexts with different explanations regarding its genesis and its role in landscape evolution. The place of study of the present study is located in the region of the city of Espera Feliz-MG, located in the southern portion of Serra do Caparaó, which features in its landscape scenery the presence of these features. Therefore, this work aimed to integrate remote sensing and spatial analysis and processing techniques, integrating physical variables such as pedology, hydrography, hypsometry, slope and lithology, in order to evaluate dispersion and concentration patterns in the landscape of the place of study. The results showed that there is a topographical / geomorphological pattern of occurrence for the 108 features identified, that is, an intermediate landscape compartment formed by hills and policonvex hills, more precisely in their slopes. In the joint, it is believed that they are scars of mass movements or other forms of erosion, revealing an intimate association between pedogenesis and morphogenesis in the regional landscape.
\end{abstract}

Keywords: Remote sensing; Closed Depressions; Landscape Evolution. 


\section{INTRODUÇÃO}

As depressões fechadas são definidas por Filizola e Boulet (1996) como formas de bacia que não possuem um fluxo de saída, cuja origem é a subsidência da superfície pela perda geoquímica de material solúvel de base. Estudos acerca das depressões fechadas vêm buscando compreender melhor qual contexto paisagístico é capaz de favorecer a sua ocorrência. O consenso a respeito desse entendimento diz respeito ao fato de que sua associação está ligada com a dinâmica dos agentes atuantes na cobertura pedológica e que, geralmente, estão associadas a lineamentos estruturais regionais. Na região sudeste do Brasil, esse tipo de depressão é comum e ocorre em diferentes contextos litológicos, pedológicos e topográficos (MATEUS, 2015).

A porção leste do estado de Minas Gerais, na divisa com o estado do Espirito Santo, o município de Espera Feliz, intitulado neste trabalho como região de Espera Feliz, apresenta em seu contexto geomorfológico, cavidades convexas semelhantes às feições descritas pela comunidade científica, e intituladas de depressões fechadas por Mateus (2015). Trabalhos como o da autora buscaram compreender a origem das depressões nessa região e o fizeram por meio do estudo da cobertura pedológica através de levantamento geofísico e análises macro e micromorfológicas. Como conclusão, esses estudos sinalizam para o fato de que as feições sugerem não possuir relação com o aprofundamento do manto de alteração, mas, de outra maneira, com a sua remoção. Longe de confrontar as propostas até então feitas, esse estudo apenas apresenta a possibilidade de que naquela região outros processos estejam corroborando para gerar feições semelhantes àquelas pioneiramente descritas por Filizola e Boulet (1996).

Apesar de o estudo mencionado contemplar aspectos acerca da gênese destas depressões fechadas, a caracterização a respeito da distribuição espacial das mesmas na região de Espera Feliz ainda é uma lacuna a ser preenchida, já que o estudo esteve restrito a apenas algumas unidades e em uma mesma vertente. Além da distribuição na área estudada, a caracterização do contexto geológico, geomorfológico e pedológico tem potencialmente a capacidade de contribuir com o entendimento da formação dessas feições e de sua importância em contexto regional, sobretudo em relação à evolução da paisagem.

Diante dessa perspectiva, as técnicas que envolvem o Sistema de Informações Geográficas (SIG) e os métodos de análise espacial, são de grande auxilio no que se refere a compreensão da alteração da paisagem, uma vez que permite a integração de diferentes informações, tais como litologia, pedologia, relevo, nas mais diversas escalas de análise. Para a caracterização de formações superficiais da paisagem, Crósta (1993), Rocha e Souza Filho (2013) e Silva (2015), mostram o potencial do Sensoriamento Remoto como uma ferramenta eficiente e de fácil acesso para o público 
em geral. Uma vez que os dados para modelagem são obtidos remotamente e o tratamento dos sensores multiespectrais de satélites como o Landsat e o ASTER têm oferecido resultados satisfatórios (SILVA, 2015).

Sob o enfoque acima abordado é que este trabalho buscou se debruçar, associando o interesse em se compreender a distribuição espacial das feições tratadas como depressões fechadas às potencialidades oferecidas pelas geotecnologias para esse fim.

\section{CARACTERÍSTICAS DA ÁREA DE ESTUDO}

O município de Espera Feliz situa-se no interior do estado de Minas Gerais, na mesorregião da Zona da Mata, fronteira com o estado do Espirito Santo (Figura 1), ao sul do Parque Nacional do Caparaó. O município encontra-se a $379 \mathrm{~km}$ de distância do munícipio de Belo Horizonte e cerca de $30 \mathrm{~km}$ do Pico da Bandeira.

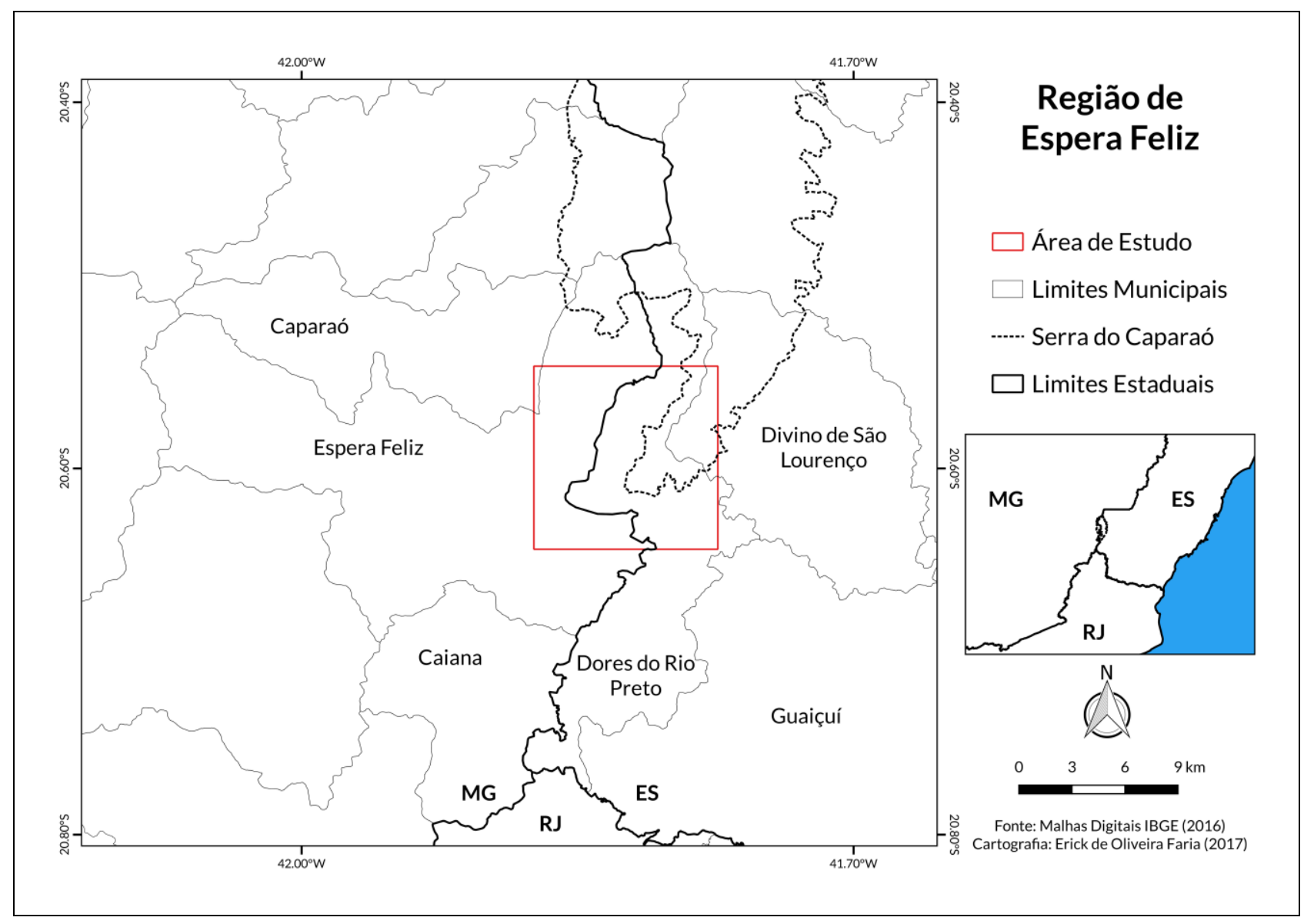

Figura 1 - Mapa da localização da área de estudo Fonte: Elaboração própria. 


\subsection{Geologia}

O contexto geológico da Região de Espera Feliz, como descrito por Novo et al. (2001) e por Horn et al. (2007) envolve a Província Estrutural Mantiqueira, que é um sistema orogenético com sentido preferencial NE-SW. Na província da Mantiqueira, tem-se vários orógenos presentes, sendo eles Dom Feliciano, São Gabriel, Araçui e Ribeira. A Figura 2 mostra a ocorrência de formações do Neógeno, que são representadas pela existência de pequenos depósitos aluvionares (SILVA, 2015).

A geologia da área de estudo situa-se na fronteira entre os orógenos Araçuaí e Ribeira, no setor meridional do domínio interno do sistema orogênico brasiliano (Pedrosa-Soares et al. 2001, Silva et al. 2005). A maior parte das unidades geológicas são pré-cambrianas (complexos Juiz de Fora e Paraíba do Sul, e intrusões que cortam estas unidades), os depósitos mais jovens incluem aluvião e colúvio com alguns resíduos provenientes de pegmatitos (HORN, 2007).

$\mathrm{Na}$ área de estudo são reconhecidas unidades litológicas pertencentes ao Proterozoico e ao Paleoproterozoico, sendo eles a Suíte Caparaó e o Grupo Andrelândia, respectivamente (SILVA, 2015). A Suíte Caparaó, segundo Horn et al. (2007) e por Novo et al. (2001), tem em sua composição rochas enderbítica, charnockítica, quartzodiorítica, gabróica e norítica, sendo, genericamente, o gnaisse ortoderivado o principal litotipo da área. Esses gnaises tem bandamento preferencial NNE e enclaves máficos com presença de plagioclásios, ortopiroxênios e clinopiroxênios (SILVA, 2015).

O Grupo Andrelândia localiza-se na borda leste do estado de Minas Gerais e segundo a recente classificação de Horn et al. (2007) insere-se nas macro-faixas orogenéticas de Araçuaí e Ribeira. Este grupo é caracterizado pela presença de paragnaise granatíferos e moscovíticos, ou quartizíticos (SILVA, 2015). Neste compartimento tectônico ocorre uma intercalação entre os metassedimentos e as rochas do embasamento pré-1,7 Ga, sendo ambos metamorfizados em fáceis granulito (TUPINAMBÁ et al., 2007).

As porções mais baixas do relevo, como vales dos rios concentram os depósitos aluvionares, de suposta idade holocênica (SILVA, 2015). Estes depósitos são interpretados por Silva (2015) como sendo do tipo fluvial in situ, com características que variam entre argilosas e arenosas, com ocorrências de cascalho que moldam as curvas dos rios. 


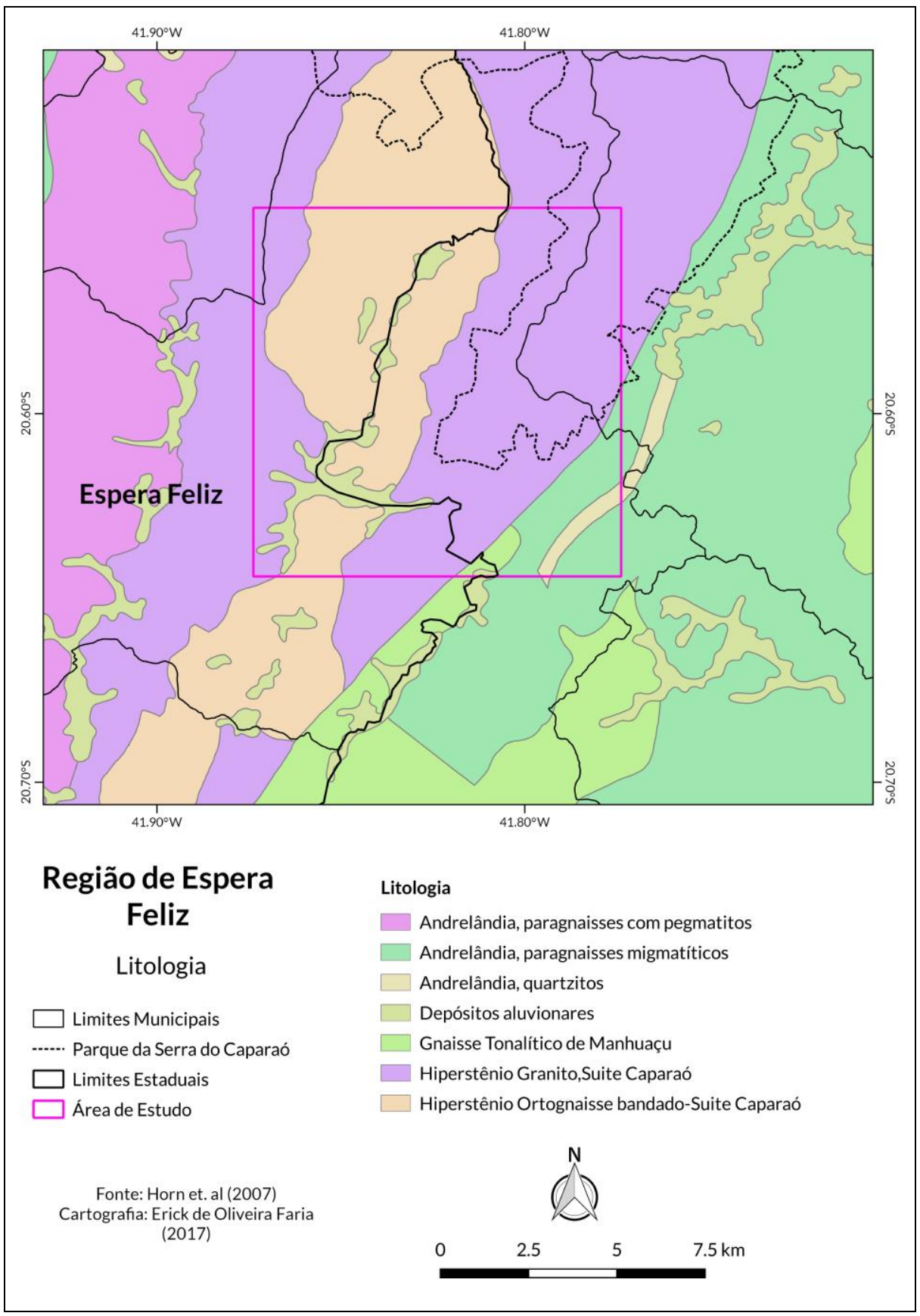

Figura 2 - Mapa geológico da região de Espera Feliz Fonte: Adaptado de Horn et al. (2007).

\subsection{Geomorfologia}

A área é marcada por uma geomorfologia com um forte controle estrutural, no qual é descrito por Soares (2013) a presença de serras alongadas e espigões seguindo a direção das rochas no sentido NNE-SSW. A região apresenta segundo Horn et al. (2007), cotas com padrões que variam de 800 a 1.100 metros, tendo uma quebra no padrão estrutural no pico da bandeira. Na serra do Caparaó, a nordeste do limite municipal, conforme mostra a figura 3 a cota apresenta valor máximo de 3.000 metros. 
O mapa hipsométrico, (figura 3) nos mostra um relevo muito irregular, com uma grande variação de altitude na área de estudo. Existe ainda um conjunto de serras homogêneas que se repetem ao longo da paisagem em suas bases como terraços fluviais, no qual há presença de rios e corredeiras com variáveis fluxos, conforme a diferença topográfica (SILVA, 2015).

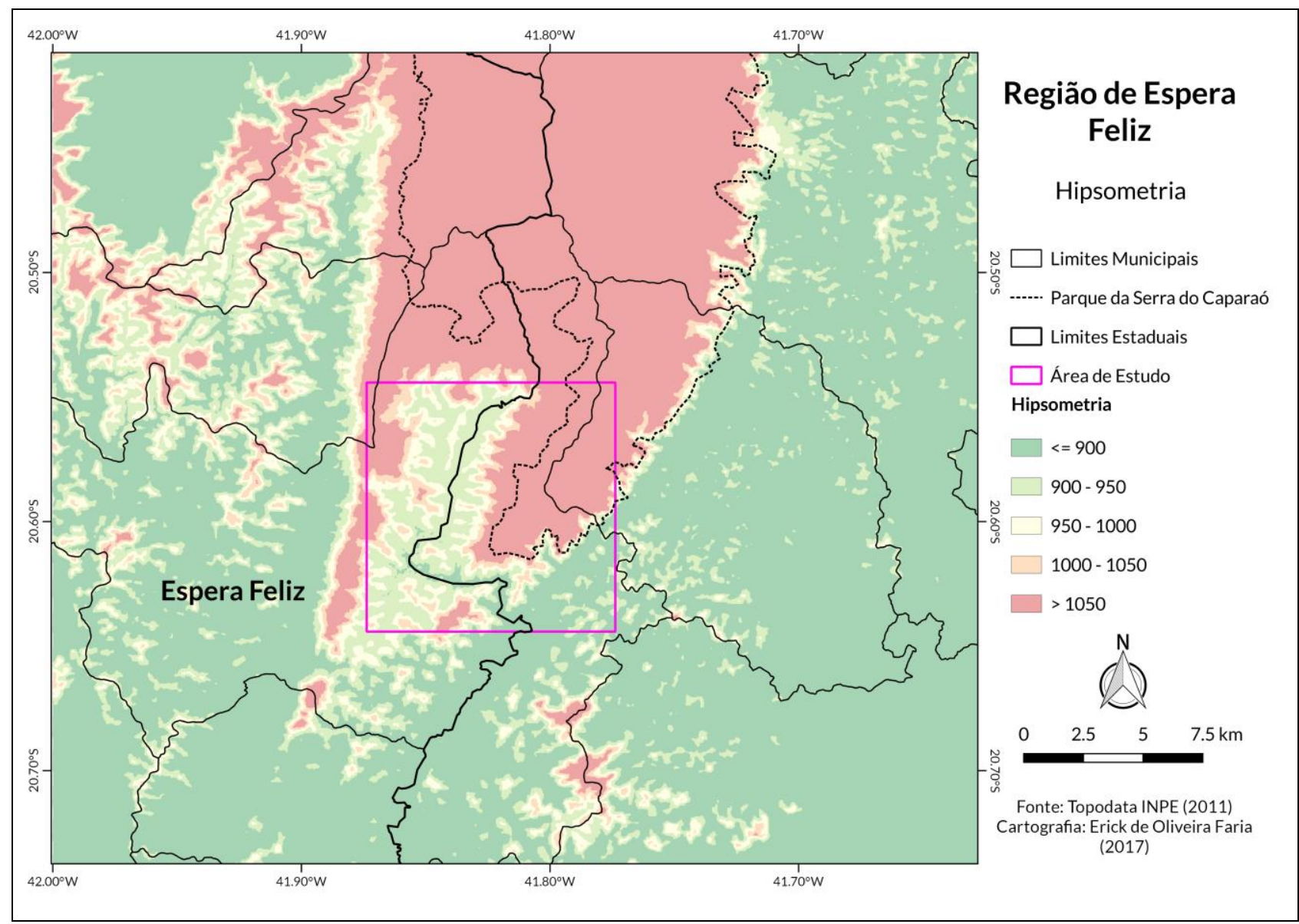

Figura 3 - Mapa Hipsométrico da região de Espera Feliz

Fonte: Elaboração própria, a partir dos dados da EMBRAPA (2005).

$\mathrm{Na}$ figura 4 observam-se cavidades nas vertentes, semelhante a anfiteatros, que Soares (2013) interpreta como "resultante de escorregamentos pretéritos". Por outro lado, como citado por Soares (2013), cavidades com semelhantes morfologias são interpretadas por Coelho Netto (2003) como "proto-vales que evoluem para cavidades estruturais suspensas ou ajustadas ao vale". Outros estudos como o de Filizola e Boulet (1982) associa que nesta região as "depressões teriam sua gênese associada a movimentos de massa nas vertentes impulsionados por reativações neotectonicas". 


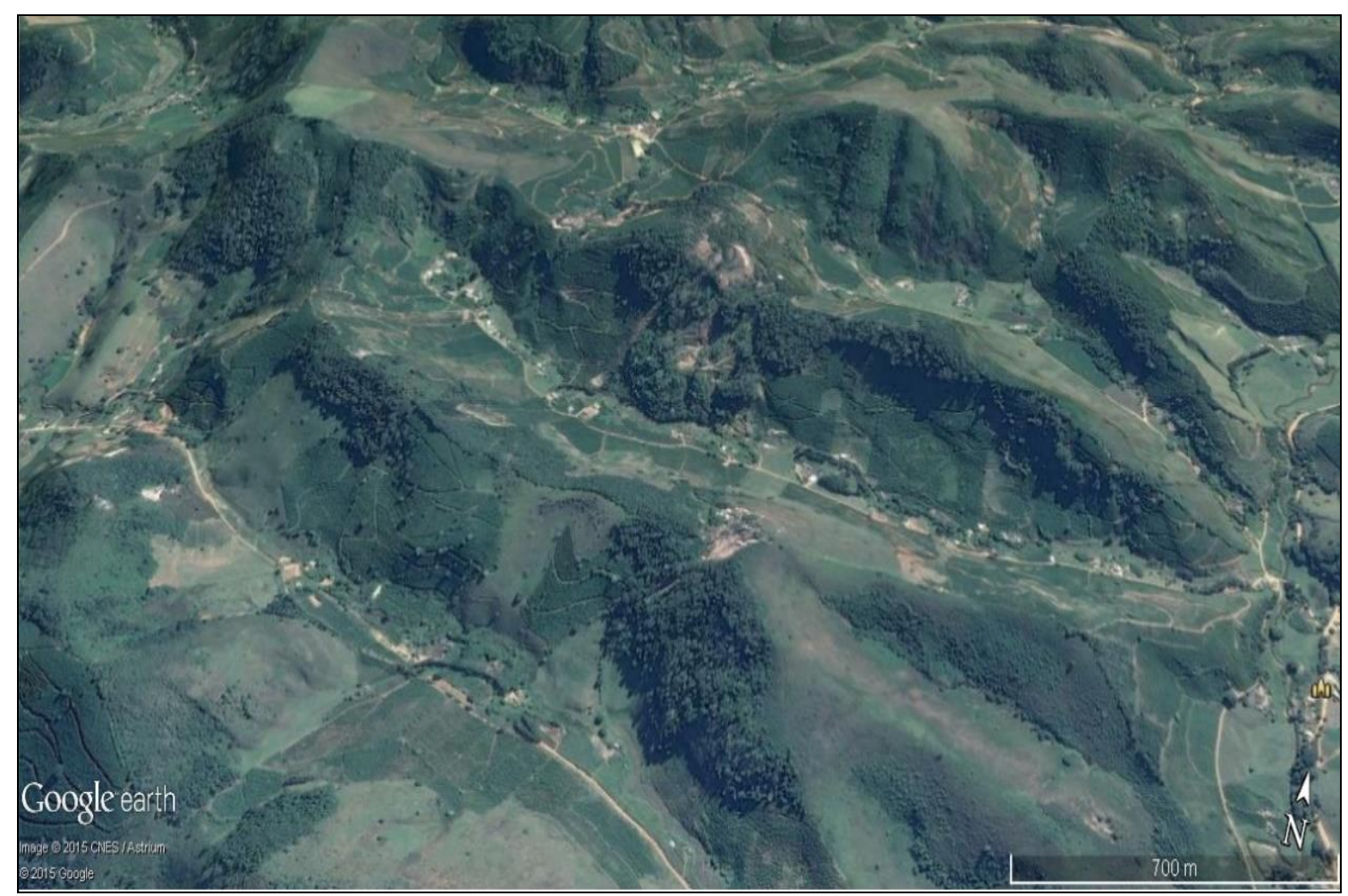

Figura 4 - Imagem de satélite do relevo de Espera Feliz. Fonte: Google Earth (2015).

\subsection{Pedologia}

Na região de Espera Feliz há uma grande diversidade pedológica, podendo ser encontrado segundo Silva (2015) solos de coloração vermelho-amarelada, resultante da atuação intensa de processos de intemperismo e pedogênese, em solos rasos até profundos.

O mapa de solos da EMPBRAPA (2012) de escala 1:5.000.000 representado na figura 5 nos mostra uma variação de quatro combinações de solos no município de Espera Feliz, sendo de maior predominância o LVA Distrófico (Latossolo Vermelho-Amarelo) e em menores ocorrências os solos Cx Tb Distrófico (Cambissolo Háplico) e PVA Distrófico (Argissolo Vermelho-Amarelo).

Em maior ocorrência temos representado de cor azul os solos Cx Tb Distrófico + LVA Distrófico, que ocupa áreas de sul ao norte e nordeste do município de Espera Feliz, ocorrendo segundo Silva (2015) em áreas de relevo que variam de plano a ondulado. A área de ocorrência dos solos LVA Distrófico + Cx Tb Distrófico se dá em menor parte na região sudeste do município. Na parte oeste temos a ocorrência de três solos, sendo eles LVA Distrófico + LVA Distrofórrico + CX Tb Distrófico, o mesmo ocorre na parte central e sudoeste do município, porém com tipos de solos diferentes, sendo eles LVA Distrófico + LVA Distrofórrico + PVA Distrófico. 


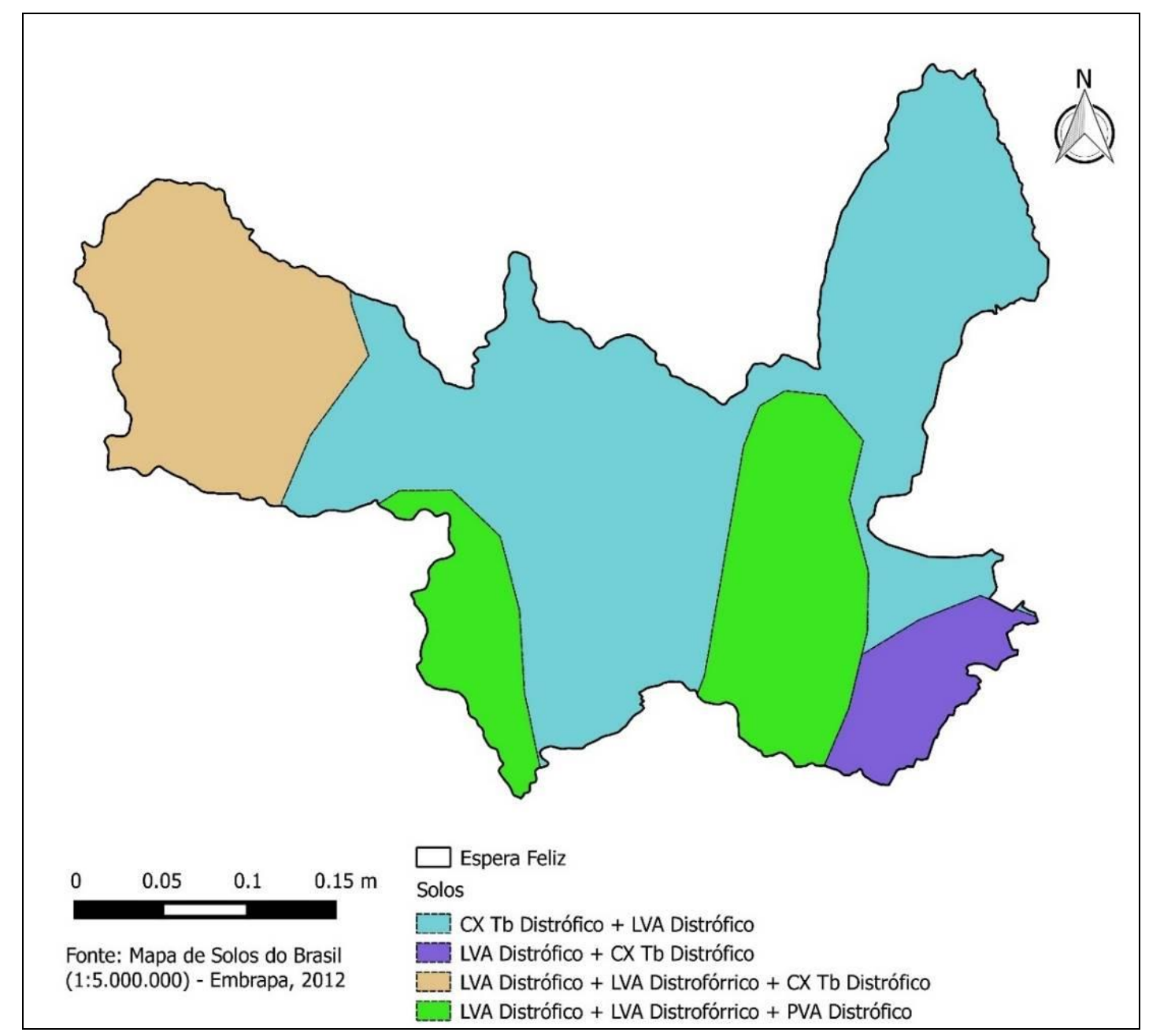

Figura 5 - Mapa pedológico de Espera Feliz.

Fonte: Elaboração própria, a partir dos dados da EMBRAPA (2012).

Em menor ocorrência temos o LATOSSOLO VERMELHO, que ocupa uma área na porção sudoeste da região de estudo. Silva (2015) justifica a cor vermelha do solo como resultante da quantidade do mineral hematita na mineralogia oxídica do solo, também aponta sua ocorrência em áreas de relevo forte ondulado e montanhoso.

Pequenas porções, que não são representadas na figura 5, de GLEISSOLO HÁPLICO e de NEOSSOLO LITÓLICO, ocorrem em áreas de baixada, próximo aos canais fluviais (SILVA, 2015). Nos setores meandros abandonados e locais de condições hidromórficas os GLEISSOLOS predominam, e em locais onde pacotes de sedimentos foram remobilizados os NEOSSOLOS FLÚVICOS são predominantes (SILVA, 2015). Vale ressaltar que, por ser um mapa de escala muito pequena, sua análise limita-se apenas ao caráter exploratório, podendo haver tipos de solos negligenciados na figura 5 . 


\subsection{Cobertura vegetal}

A cobertura vegetal remanescente da região de Espera Feliz foi em grande parte removida, restando apenas algumas áreas de reservas particulares e as reservas protegidas por leis, como parques estaduais ou nacionais, como o Parque Nacional da Serra do Caparaó (SILVA, 2015). A mata atlântica (Floresta Subhumida do Interior) com exceção de alguns locais na paisagem, foi praticamente extinta devido a ação antrópica. A ação antrópica que mais degradou a cobertura vegetal nativa da região é, segundo Horn et al (2007), as queimadas. Em segundo a retirada da madeira e em terceiro plano a plantação de algodão.

Hoje a vegetação que prevalece na região é marcada por fragmentos florestais e extensas áreas cobertas por plantações e espécies utilizadas para o pastoreio. O café é apontado por Silva (2015) como a segunda cobertura vegetal mais abundante, tendo sua ocorrência em diversos locais, inclusive em vertentes muito íngremes.

\subsection{Clima}

Segundo Horn (2007) o clima na área de estudo é subtropical a tropical com duas estações bem definidas, sendo elas: i) Chuvas intensas concentradas no período de novembro até abril e ii) seca que se alonga pelo resto do ano.

Anualmente a pluviosidade apresenta variações em torno de $1600 \mathrm{~mm}$ com o pico de $2200 \mathrm{~mm}$ em algumas regiões. A temperatura média da área é de $25^{\circ} \mathrm{C}$, sendo as maiores temperaturas, identificadas nos meses de dezembro e janeiro com $40^{\circ} \mathrm{C}$ e as temperaturas mais baixas no inverno com uma temperatura que chega a $15^{\circ} \mathrm{C}$. (HORN, 2007)

\section{SENSORIAMENTO REMOTO COMO AUXÍLIO NA INTERPRETAÇÃO DA PAI- SAGEM}

O sensoriamento remoto constitui-se um conjunto de técnicas muito utilizado atualmente para caracterização da paisagem. As técnicas são constituídas basicamente do tratamento de imagens pela aquisição de imagens dos satélites orbitais, sendo possível o seu uso nas mais diversas aplicações no campo das geociências.

O potencial do sensoriamento remoto é demonstrado por Rocha e Souza Filho (2013) e Crósta (1993) como ferramenta capaz de identificar e caracterizar formações superficiais. Atualmente com o grande acervo de imagens de satélites e ferramentas gratuitas disponíveis na internet, o 
sensoriamento remoto é uma ferramenta que apresenta uma boa relação custo-benefício. Algumas empresas como a Google Inc disponibilizam através de projetos, como por exemplo, o software Google Earth que distribui gratuitamente imagens de satélites com atualizações constantes e de fácil manuseio para o público em geral.

Existem diferentes tipos de satélites que variam de acordo com a sua finalidade. Entre os satélites mais utilizados temos os militares, científicos (Aster, Modis), os meteorológicos (NOAA, QuickStart) e os de Recursos Naturais (Spot, CBERS, Ikonos, Quickbird, Landsat). Estes satélites contam com sensores que são capazes de identificar respostas espectrais oriundas da radiação refletida ou absolvida pela superfície estudada, resultando em seguida em uma imagem matricial. São estes diferentes sensores orbitais e as diferentes resoluções espaciais e radiométricas que permitem a investigação das características morfogenéticas da paisagem.

O INPE (Instituto Nacional de Pesquisas Espaciais) é o órgão responsável pelas primeiras pesquisas no campo do Sensoriamento Remoto no Brasil. Hoje profissionais das mais diversas áreas do conhecimento, espalhados por todo o Brasil, realizam trabalhos utilizando o sensoriamento remoto em seus estudos, contribuindo para a ampliação do acervo de imagens digitais.

Um dos métodos de reconhecimento da superfície terrestre através técnicas de sensoriamento remoto é o modelo de land systems, que permite através dos padrões de fisionomias do terreno identificar características de transformação da paisagem. Os dados morfométricos devido a sua facilidade de aquisição e confiabilidade de informações é um dos que mais se destacam dentre as diversas variáveis fisionômicas. Uma análise quantitativa e de correlação com outras características físicas é possível através da interpolação das informações disponíveis neste modelo (PANQUESTOR et al, 2002).

As imagens dos satélites permitem que seja feito o reconhecimento da superfície terrestre em seu estado atual e ao comparar imagens em uma escala temporal, permite a caracterização da transformação da paisagem de forma remota. Apesar de ser uma ferramenta capaz de trazer resultados precisos, há quem critique o sensoriamento remoto como ferramenta única para a caracterização da paisagem. Estes defendem o sensoriamento remoto como uma ferramenta auxiliar ao trabalho de campo a ser realizado.

Estudos utilizando o Sensoriamento Remoto através de classificação de imagens vêm demonstrando resultados satisfatórios. Silva (2015) apresenta a eficiência no tratamento de imagens do sensor ASTER para a identificação das ocorrências de bauxita na região estudada. 


\subsection{Depressões fechadas}

As depressões fechadas são feições topográficas de formato côncavo que tem sua ocorrência não conectada com a drenagem atual, que tem como principal mecanismo de formação a denudação química (FILIZOLA; BOULET, 1996).

A ocorrência das depressões fechadas já foi alvo de vários outros estudos, e tem sua ocorrência situada na Região de Espera Feliz e em outras regiões do sudeste do Brasil. No platô de Itapetininga, Castro (1980) identificou a presença das depressões fechadas em rochas da Formação Serra Geral. No compartimento Três Cantos, Alves (2014) identificou a presença de depressões fechadas sobre rochas basálticas, concentradas em solos de textura média. Feições semelhantes e também em áreas de rochas basálticas foram identificadas por Feltran Filho (1997) nas áreas planas de chapadas de Uberlândia, Minas Gerais. Em formações ferríferas bandadas Pereira et al. (2012) identificou a ocorrência dessas feições na região do Quadrilátero Ferrífero. No médio Vale do Rio Paraíba do Sul, Castro e Coelho Netto (2002) caracterizaram a ocorrência de depressões fechadas em gnaisse e xisto da unidade São João.

O motivo da ocorrência das depressões fechadas é apontado majoritariamente pelos autores como uma relação entre a estrutura pedológica e a sua suscetibilidade a resistência do substrato por lixiviação diferencial (FILIZOLA; BOULET, 1996; COELHO NETO, 2003; UAGODA et al., 2006). Os estudos reconhecem que a formação das depressões fechadas tende a influenciar a evolução da cobertura pedológica, uma vez que irá perturbar o processo pedogenético atuante.

A gênese das depressões fechadas está vinculada com a transformação da cobertura pedológica, sendo ambos indicadores importantes para a compreensão de um e do outro (MATEUS, 2015). Em casos que sinalizam a origem dessas feições como produtos da lixiviação preferencial são encontrados no interior das coberturas pedológicas solos mais desenvolvidos do que no seu entorno (FILIZOLA \& BOULET, 1996; COELHO NETO, 2003; UAGODA et al., 2006)

O estudo de Castro e Coelho Netto (2002) identificou o desenvolvimento de depressões fechadas em uma áreade cobertura latossólica, que tinha como processo pedológico ali atuante a latossolização; este processo gerou um argissolo hidromórfico devido a perturbação gerada pela depressão fechada. Castro \& Coelho Netto (2002) sugerem que uma zona de percolação subvertical favoreceu a formação da depressão fechada por subsidência geoquímica, rebaixando assim o latossolo que estava ali presente e transformando-o por lessivagem e hidromorfia. A transformação na gênese pedológica foi identificada também por Rosolen e Herpin (2008), que verificaram transformação na montante, a partir do centro da depressão, através da expansão dos horizontes hidromórfi- 
cos, pois, a exportação da matéria particulada ali presente, era modificada ou dissolvida, modificando a textura e a estrutura, acarretando na diminuição do volume do solo e do relevo.

Ao contrário dos estudos citados, as vertentes no interior das depressões fechadas na região de Espera Feliz, apresenta o adelgaçamento da cobertura pedológica com um horizonte organomineral sotoposto por fragmento de bauxita (MATEUS, 2015). Estes atributos identificados nos perfis neossólicos confirmam a associação em porções residuais dos latossolos erodidos (MATEUS, 2015)

\subsection{Depressões fechadas na região de espera feliz}

Na região de Espera Feliz o estudo mais completo que se tem acerca das depressões fechadas feito por Mateus (2015), buscou compreender a origem das depressões fechadas associadas a cobertura laterítica aluminosa. Utilizando de métodos geofísicos de análise, Mateus (2015) buscou compreender como essas feições se relacionam com a evolução da couraça bauxitica. Outros trabalhos como o de Silva (2015), que estudou a ocorrência de bauxita em áreas de concomitante ocorrência das depressões fechadas, e o trabalho de Soares (2013), também contribuíram acerca do tema em estudo.

O trabalho de Mateus (2015) evidenciou a presença de diferentes solos ao longo da vertente, tendo variações na classificação do interior das depressões de solos mais novos (Neossolo Litólico Húmico típico) a solos mais antigos nas bordas (Latossolo Vermelho-Amarelo distrófico húmico). Mateus (2015) associa as diferenças morfológicas dos solos dentro da vertente como um reflexo da sua própria evolução pedogeomorfológica, que ocorreu em dois momentos, sendo eles: a formação de uma cobertura latossólica pela degradação da bauxita - fato esse evidenciado também por Silva (2015), e a transformação por mecanismos morfogenéticos da cobertura latossólica, originando as depressões fechadas.

A figura 6 nos mostra em destaque uma depressão fechada no topo de um morrote na Região de Espera Feliz. As depressões fechadas concentram-se nos topos desses morrotes entre cotas que variam de 800 a 900 metros, e são separados entre si por vales entulhados de sedimentos com morfologia aplainada (SILVA, 2015).

Nas depressões fechadas da região de Espera Feliz foram identificadas ocorrências de cobertura bauxita (FILIZOLA; BOULET, 1996). Segundo Silva (2015) a distribuição dos pontos em que há ocorrência de bauxita não representam grandes aglomerados, mas apenas ocorrências pontuais de significativa presença, mas que, acompanham a distribuição espacial das depressões fechadas. As ocorrências destas bauxitas vão sendo encontradas na paisagem em topos residuais a altitudes de 
800 e 1000 metros seguindo um padrão de distribuição de outros locais na Zona da Mata e Leste mineiro (LOPES, 1987). A ocorrência de bauxita no município de Espera Feliz está, para Filizola e Boulet (1996), associada a estas feições de relevo de formato côncavo.

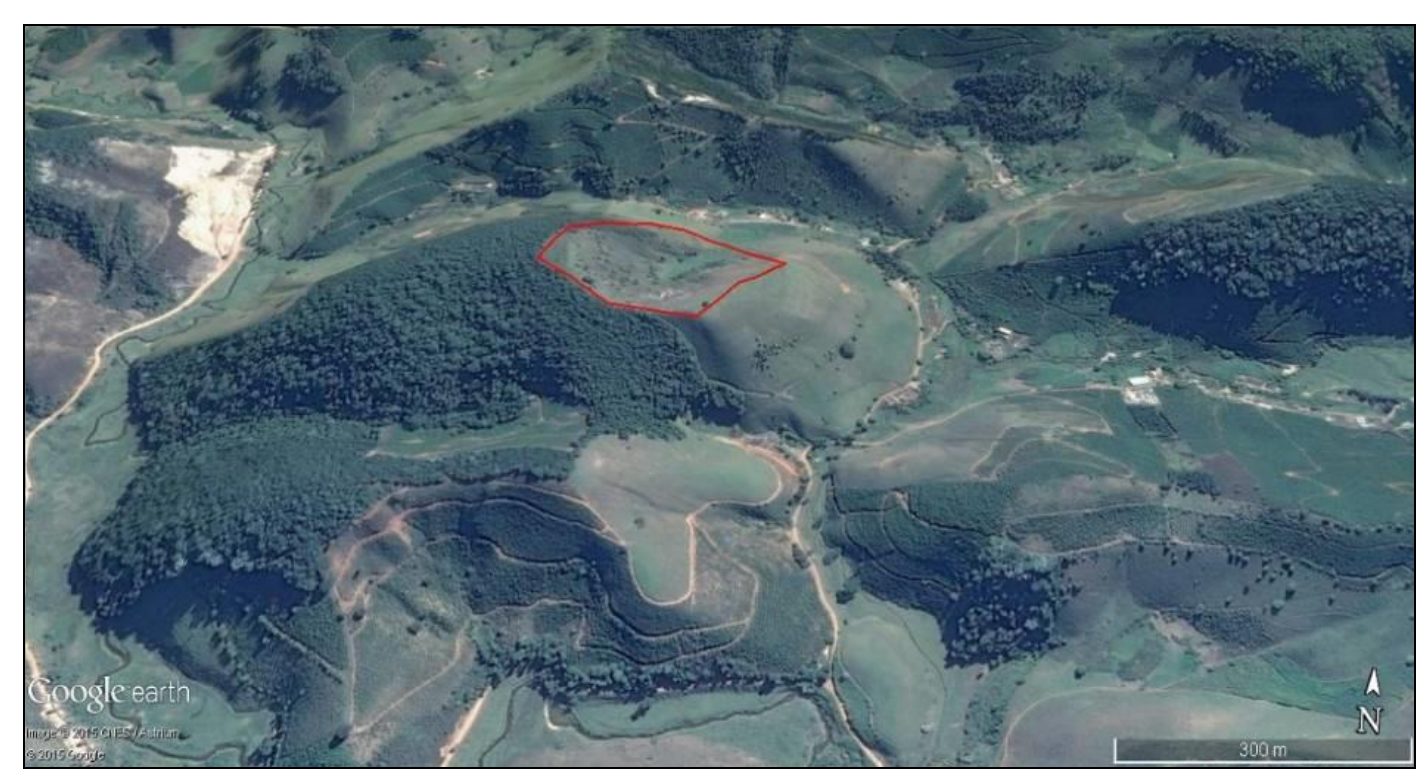

Figura 6 - Depressão Fechada no topo de um morro em Espera Feliz Fonte: Google Earth, 2016.

A degradação geoquímica dessa bauxita é apontada por diversos autores como resultado de mudanças das condições ambientais, como a oscilação climática, do nível freático e colonização vegetal de maior porte (MATEUS, 2015). Um espesso pacote de argilas-cauliniticas é identificado por Mateus (2015) acima da bauxita fragmentada sendo vinculada ao avanço vertical da degradação da bauxita e a bioturbação promovida pelos organismos. Para Mateus (2015) atributos analíticos corroboram com a gênese da cobertura latossólica na região de Espera Feliz.

A gênese das depressões na área deste estudo sempre foi interpretada como produto da alteração diferencial de rochas, seguindo os lineamentos estruturais. Estudos como o de Filizola e Boulet (1982) e mais recentemente o de Mateus (2015) associam a gênese das depressões fechadas na área de estudo à "combinação entre processos de movimentação de massa em períodos áridos com reativação tectônica".

\section{MATERIAIS E MÉTODOS}

A etapa inicial deste trabalho se deu em uma revisão bibliográfica acerca das depressões fechadas e sua distribuição nos mais diversos contextos, e de outras pesquisas realizadas na área de estudo, a fim de se ter um quadro fisiográfico geral da área. Para isso foi levantada toda bibliografia referente ao sensoriamento remoto e os modos de aplicação para estudo da paisagem e caracteriza- 
ção do objeto de estudo. Uma revisão bibliográfica sobre as depressões fechadas também foi realizada buscando compreender melhor o fenômeno e suas características em áreas distintas e semelhantes. Esta etapa inclui o levantamento das bases cartográficas, orbitais e espectrais disponíveis para a área de estudo.

\subsection{Mapeamento de ocorrências e do contexto na paisagem}

A análise e mapeamento de ocorrências (das depressões na paisagem) na área de estudo se deu pelo emprego de técnicas de Processamento Assistido de Imagens de Satélite. Analisando as bases cartográficas disponíveis, sua qualidade e disponibilidade, optou-se por trabalhar com a imagem do satélite Landsat-8. Para os procedimentos de tratamento de imagem em laboratório, foi utilizada a imagem com a área SF.24-V-A-IV - Espera Feliz (CPRM, 2007) na escala de 1:100.000, sendo compreendida pelas coordenadas $188000 \mathrm{mE}$ e $212000 \mathrm{mE}$ e $7728000 \mathrm{mN}$ e $7708000 \mathrm{mN}$.

A partir da imagem, foi criado um polígono da margem externa da imagem no software QGIS 8.3, gerando um arquivo shapefile para delimitação da área de estudo. Com a delimitação da imagem através do polígono no software Google Earth foi realizado o mapeamento das depressões fechadas dentro dos limites desta imagem. O mapeamento das depressões foi feito por interpretação visual das imagens, através do seu reconhecimento a partir das características morfológicas dessas unidades. A partir de sua identificação, foi criado um polígono circundando cada feição, posteriormente gerando um mapa temático de ocorrências.

De maneira a obter propriedades morfométricas das feições identificadas, e do contexto de paisagem no qual ocorrem, foram gerados/compilados mapas temáticos baseados em variáveis hipsométricas, cobertura vegetal, geologia e solos da área de estudo.

Para a análise hipsométrica, confeccionou-se um mapa utilizando o Modelo Digital de Terreno (MDT), disponibilizados pelo programa Topodata do INPE. As cartas MDT foram interpoladas utilizando o método TOPOGRID do software ArcGis versão 10.2.2. A partir da geração do mapa MDT, confeccionou-se os mapas de declividade e hipsométrico. Após a confecção dos mapas, foram interpostas as feições geradas na etapa anterior, contendo as depressões fechadas identificadas na área de estudo.

Foi realizado um cálculo das áreas das depressões fechadas com o auxílio do software QGIS, a fim de obter uma caracterização das mesmas na paisagem. Para composição de uma estatística descritiva referente as áreas das feições, foi utilizado o software Statistical Package for the Social Sciences (SPSS). 
Para a análise da cobertura vegetal foi utilizado o Índice de Vegetação da Diferença Normalizada (NVDI), proposto por Rouse et al (1973), com a finalidade de identificar os locais de vegetação densa, vegetação rasa ou rasteira e solo exposto na paisagem, uma vez que a razão entre bandas permite a descriminação de sutis comportamentos de diferentes alvos.

As imagens utilizadas para a composição do índice NVDI foram do satélite Landsat-8, através da junção das bandas 5 e 4 do sensor OLI (Operacional Land Imager). O índice NVDI expressa a diferença entre as bandas do infravermelho próximo e do vermelho normalizada através da soma de suas bandas. 2.5 A relação para obtenção do índice NVDI é expressa na seguinte relação:

$$
\mathrm{NDVI}=\frac{\text { Banda } 5-\text { Banda } 4}{\text { Banda } 5+\text { Banda } 4}
$$

O cálculo do índice NDVI deu-se a partir da refletância de cada banda, após as mesmas terem sido transformadas em imagens de refletância de superfície (RIEDEL, et al, 2007). Sobre a imagem do índice NVDI foi sobreposto os polígonos referente as depressões fechadas identificadas na paisagem e extraídas através da interpretação visual. Após a sobreposição do polígono das depressões fechadas executou-se um recorte das imagens para uma área menor a fim de limitar-se apenas a representação da área de estudo.

Os demais mapeamentos, geológicos (1:50.000) e pedológico (1:650.000) foram compilados de bases, respectivamente, da CPRM (Projeto Leste de Minas) e da FEAM (Projeto Solos de Minas).

\section{RESULTADOS E DISCUSSÃO}

A figura 8 é uma representação morfométrica das depressões fechadas identificadas na região de Espera Feliz com uma escala ampliada (para fins didáticos), mas mantendo as proporções das mesmas. As depressões fechadas apresentaram em comum um formato arredondado, semi-circular a ameboidal, sem perímetros retos ou pontiagudos. Essa morfologia aproxima as depressões fechadas da região de Espera Feliz com aquelas descritas por Filizola \& Boulet (1996) e Castro \& Coelho Netto (2002). Nesses estudos, além do aspecto arredondado, foi observada uma assimetria e uma ligeira inclinação no sentido da vertente. Estas características morfométricas, para Coelho Netto (2003), se devem a uma tendência das depressões fechadas em evoluir para condições estruturais, acarretando na abertura para um dos lados da vertente e passando a integrar a rede de drenagem, formando anfiteatros. 
Uma estatística descritiva das informações referente a área das depressões fechadas é apresentada na tabela 1. Em média, as depressões fechadas apresentaram uma área de 29,4 $\mathrm{m}^{2}$, e uma mediana de $18,9 \mathrm{~m}^{2}$ para o universo de 108 depressões. A menor depressão fechada tem 3,03 $\mathrm{m}$ de perímetro, ao passo que a depressão de maior perímetro possui 138,4 m. Estes resultados mostram que a amplitude entre a maior e menor depressão fechada é de 135,3 metros, valor relativamente considerável levando em consideração que se encontram na mesma área.

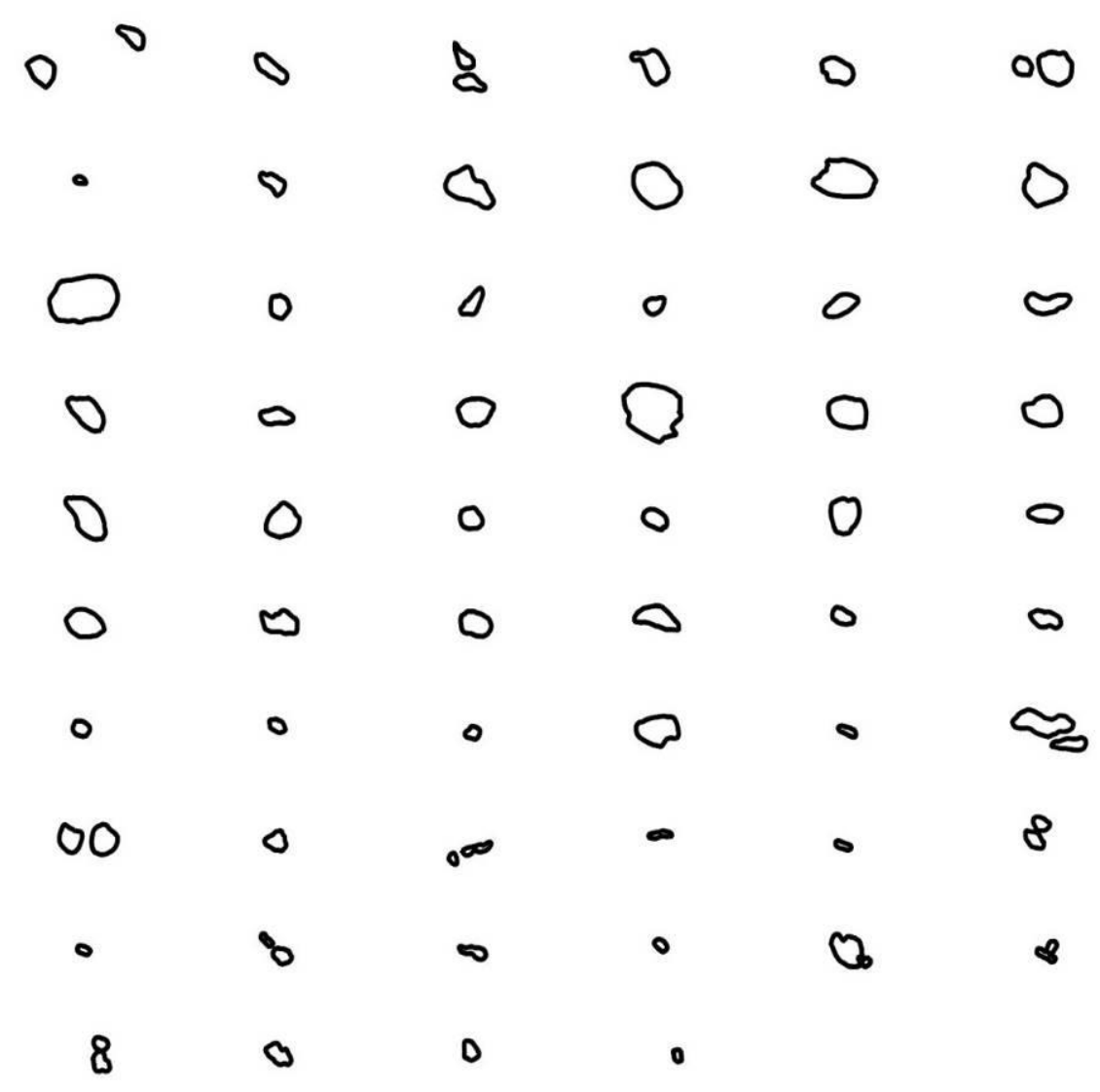

Figura 8 - Representação da morfometria das depressões fechadas mapeadas Fonte: Elaboração própria.

Tabela 1 - Estatística descritiva referente às áreas das depressões fechadas na região de espera feliz.

\begin{tabular}{ll}
\hline Estatística Descritiva das depressões mapeadas & Metros \\
\hline Média & 29,4 \\
Mediana & 18,9 \\
Amplitude & 135,3 \\
\hline Mínimo & 3,03 \\
\hline Máximo & 138,4 \\
\hline Número de depressões fechadas mapeadas & $\mathbf{1 0 8}$ \\
\hline
\end{tabular}




\subsection{Hidrografia}

A figura 9 é uma representação da hidrografia da região de Espera Feliz, realizada por Horn (2007). A hidrografia da região é composta por rios típicos de planalto devido a área de relevo mais acentuado, com canais retilíneos.

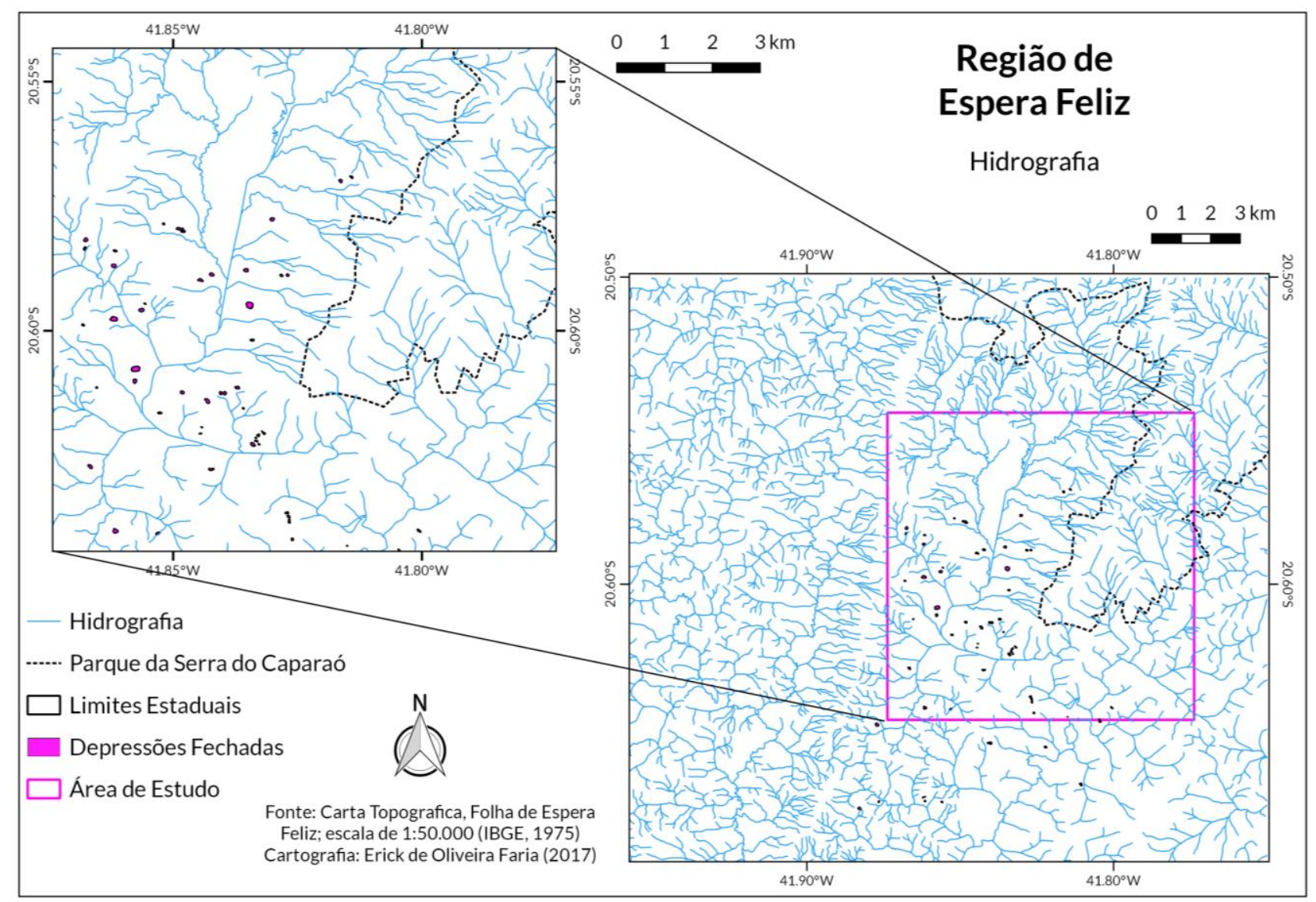

Figura 9 - Distribuição das depressões fechadas na área de estudo de acordo com a hidrografia Fonte: Elaboração própria, a partir dos dados de Horn (2007).

Os rios próximos às depressões fechadas são de $1^{\mathrm{a}}$ ordem e apresentam distâncias que variam de 70 a 755 metros em relação às feições. Dentre as 108 depressões mapeadas, 28 foram identificadas com distâncias de até 100 metros do rio mais próximo, 33 entre 100 e 300 metros e as demais 47 feições com distâncias que variaram entre 300 a 755 metros.

Para Xavier (2008), as depressões fechadas são proto-vales que tiveram sua evolução interrompida devido a mudanças locais do regime hidrológico, ou por rebaixamento do nível freático resultando em sua estabilização. Na região de Espera Feliz tal afirmação é passível de questionamentos, uma vez que as depressões fechadas apresentaram distâncias consideráveis dos rios da região e pelo fato, conforme será visto adiante, de que as depressões fechadas se encontram nas cotas 
altimétricas médias e superiores da paisagem, o que dificultaria a ação de possíveis mudanças no regime hidrológico.

A relação entre a hidrografia da região de Espera Feliz e a gênese das depressões fechadas não é muito clara, devido à falta de padrões apresentados no mapeamento das feições. A distribuição das depressões fechadas em relação aos rios na região de Espera Feliz não nos permite afirmar, por exemplo, que períodos de cheias dos rios são os responsáveis por retirar o material presente na cobertura pedológica, gerando assim as depressões fechadas. As distâncias das feições em relação aos rios são relativamente grandes, e o contexto hipsométrico das depressões fechadas na região (localizadas no topo dos morros) nos leva a questionar se um possível período de cheia seria capaz de atingir as cotas mais altas do terreno.

\subsection{Hipsometria}

A figura 10 representa a distribuição das depressões fechadas segundo a hipsometria da região de Espera Feliz, com as depressões fechadas representadas na cor verde. As feições concentram-se em sua maioria nas cotas intermediárias da região, variando entre 950 e 1000 metros de altitude. Nas regiões mais baixas, com cotas de 900 metros ou inferior, não foi identificada nenhuma feição que caracterize uma depressão fechada.

Das 108 depressões fechadas, 10 foram identificadas nas cotas de até 900 metros, 90 feições nas cotas que variam de 950 a 1000 metros, 5 feições nas cotas próximas a 1050 metros e apenas 3 nas cotas de 1100 metros ou mais. Trabalhos como Silva (2015) e Mateus (2015) já mencionaram a presença de depressões fechadas nestes morros isolados com cotas altimétricas entre 950 e 1000 metros.

Um padrão que se observa na figura 10 é a concentração das depressões fechadas no vale delimitado entre dois espigões que marcam as bordas do antiforme da Serra do Caparaó. Apenas 6 depressões foram localizadas a leste do espigão, e encontram-se fora deste padrão observado. 


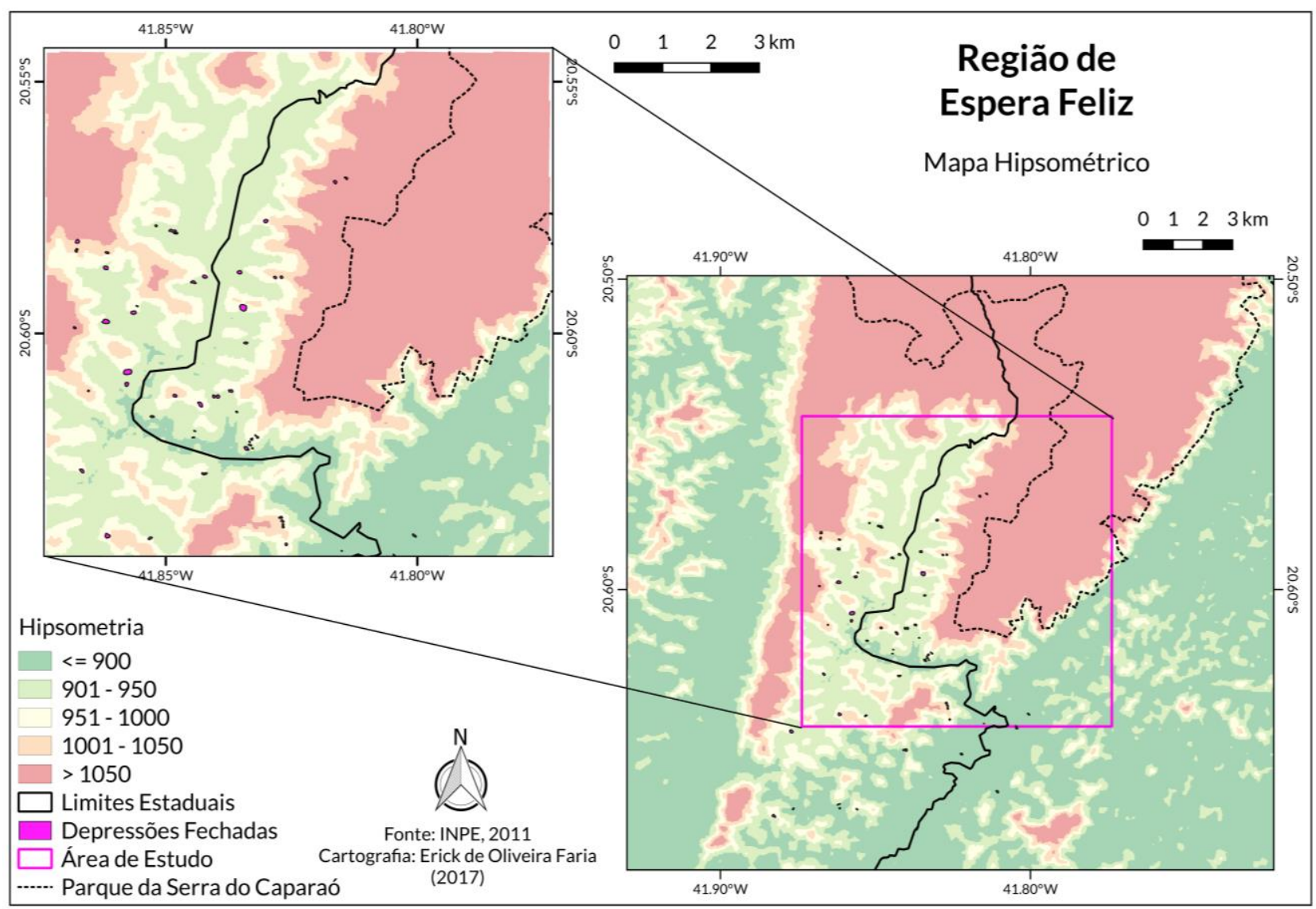

Figura 10 - Localização das depressões fechadas na região de Espera Feliz segundo a hipsometria da região.

Fonte: Elaboração própria, a partir dos dados do TOPODATA (INPE, 2011).

\subsection{Declividade}

A figura 11 é uma representação da declividade do local de estudo e a distribuição das depressões fechadas segundo a classe de declividade proposta pela EMBRAPA (1979). Conforme visto na figura 10, a hipsometria da área de estudo apresenta cotas mínimas de 900 metros de altitude, chegando a 1100 no topo da Serra do Caparaó. A declividade da região apresenta hegemonia de áreas que vão de forte ondulado, com 20 a 45\% de declividade até o escarpado com mais de $75 \%$ de declividade. Áreas com declividade suave ondulada e áreas planas são a minoria no local de estudo. As depressões fechadas foram identificadas nas partes de média declividades, sendo elas as de relevo ondulado (32), forte ondulado (70) e algumas poucas (6) em regiões de relevo montanhoso. Nas regiões de relevo plano e suave ondulado não foram identificadas depressões fechadas. 


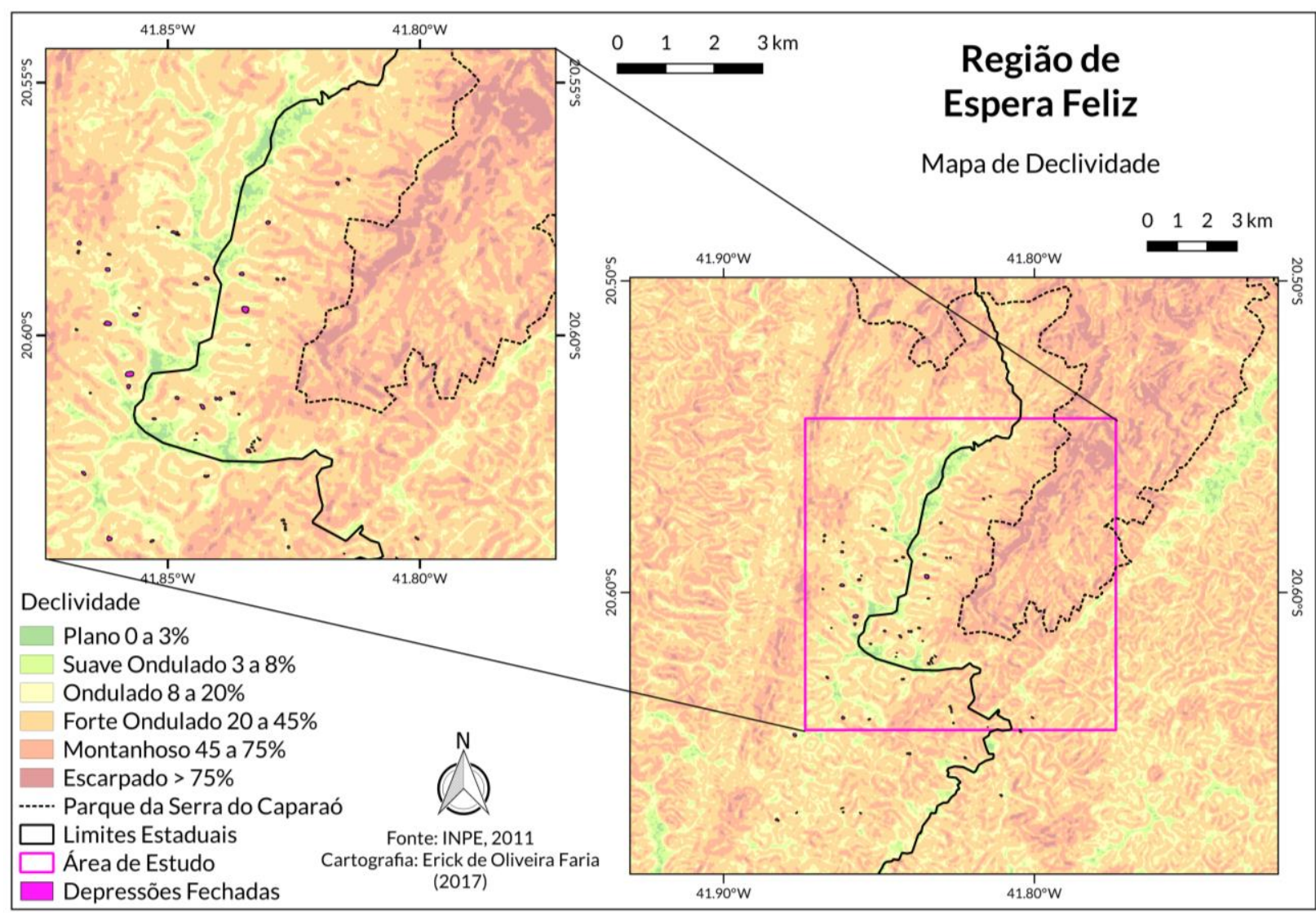

Figura 11 - Mapa de declividade da área de estudo e distribuição das depressões Fonte: Elaboração própria, a partir dos dados do TOPODATA (INPE, 2011).

\subsection{Litologia}

Foram identificadas depressões fechadas em cinco unidades litológicas na região de Espera Feliz, sendo elas: Hiperstênio Ortognaisse bandado-Suíte Caparaó, Hiperstênio Granito, Suíte Caparaó, Depósitos aluvionares, Gnaisse, Tonalítico de Manhuaçu e Paragnaisses migmatíticos do Grupo Andrelândia.

A maior parte das depressões fechadas está nas unidades Hiperstênio Ortognaisse bandadoSuíte Caparaó e Hiperstênio Granito, Suíte Caparaó, respectivamente. Quantitativamente, do total de 108 depressões, 66 estão em áreas de Hiperstênio Ortognaisse bandado-Suite Caparaó, 30 em Hisperstênio Granito, Suite Caparaó, 3 em Gnaisse Tonalítico de Manhuaçu, 2 em Depósitos aluvionares, 2 em Andrelândia quartzitos e 5 feições no Andrelândia paragnaisses migmatíticos. A unidade litológica Hiperstênio Ortognaisse bandado-Suíte Caparaó é descrita por Horn (2007) como um ortognaisse de aparência homogênea, com bandamento mais proeminente e com espessura centimétrica e decimétrica, apresenta também bandas mais e menos ricas em quartzo. 


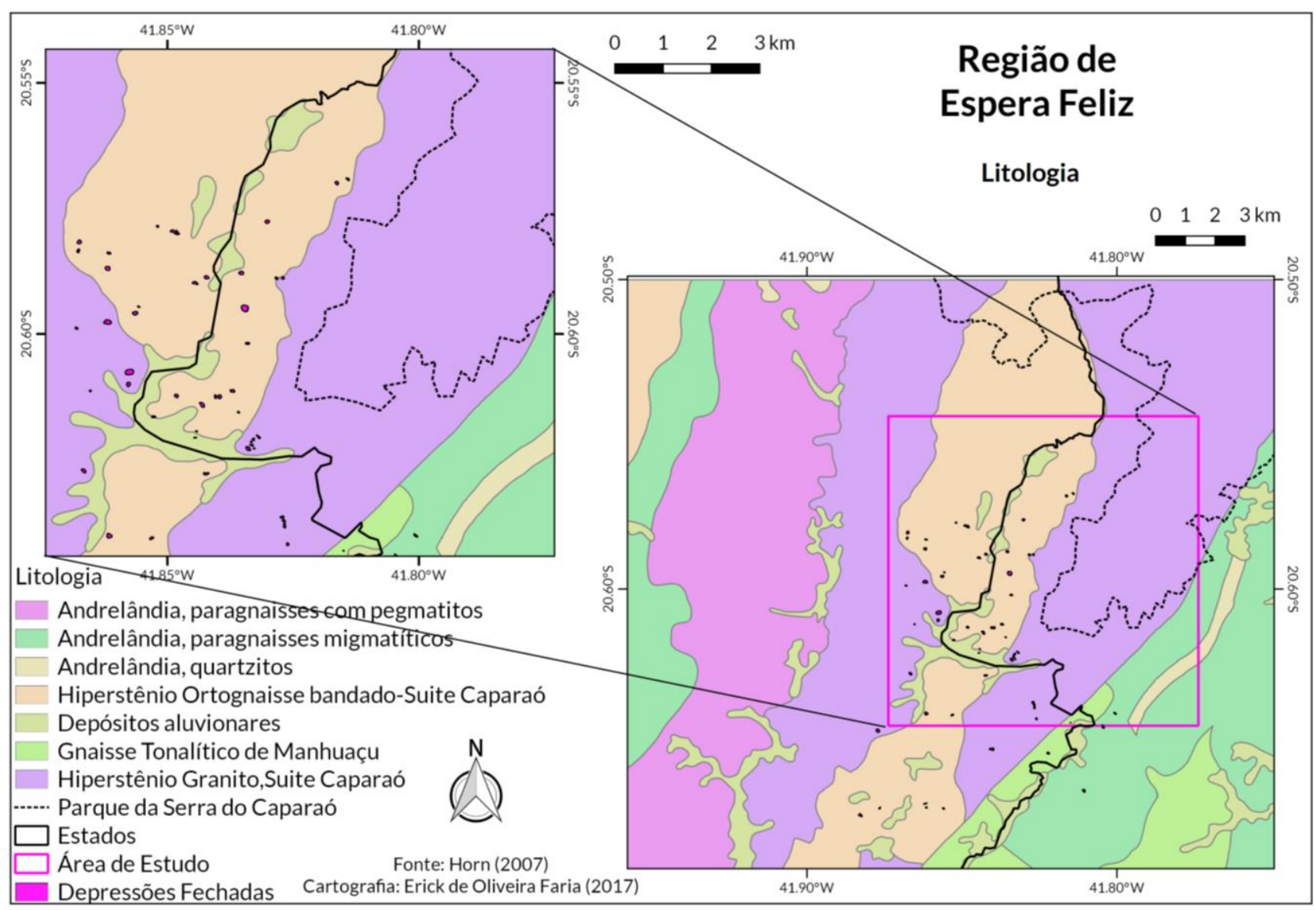

Figura 12 - Distribuição das Depressões fechadas no contexto litológico Fonte: Elaboração própria, a partir dos dados de Horn (2007).

\subsection{Solos}

Na figura 13 é possível identificar uma predominância do Latossolo Vermelho-Amarelo nas áreas em que ocorrem as depressões fechadas (FEAM, 2010). É importante ressaltar que a escala do mapeamento impõe restrições à interpretação de ocorrência. Isso porque o mapeamento é regional e oferece restrições ao detalhamento da cobertura pedológica. Por isso, dentre as 108 depressões fechadas mapeadas, 14 foram identificadas sobre Latossolo Vermelho-Amarelo Distrófico húmico, as demais 94 depressões fechadas, localizam-se sobre Latossolo Vermelho-Amarelo Distrófico típico. De maneira local, o estudo realizado por Mateus (2015) já havia retratado que há uma diferença entre os solos que ocorrem interior e no entorno das depressões. 


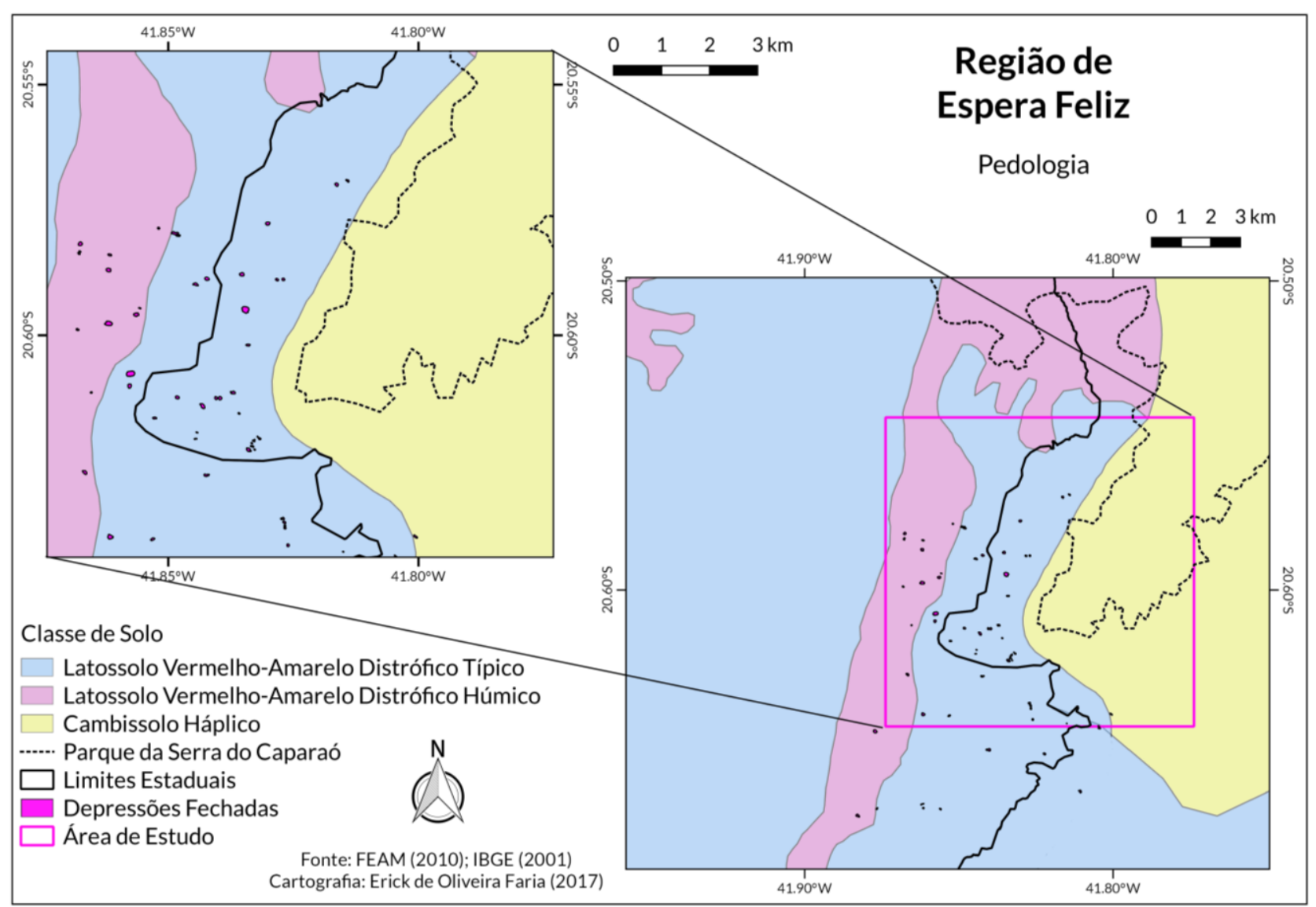

Figura 13 - Distribuição das depressões fechadas no contexto pedológico.

Fonte: Elaboração própria, a partir dos dados da FEAM (2010).

\subsection{Vegetação}

A figura 14 é a representação da vegetação na área de estudo, através do processamento das bandas 4-5 do satélite Landsat-8 com tratamento dos sensores NVDI. O índice NVDI apresenta valores que variam de -0.258 até 0.663 sendo representados em uma escala de cores que variam do vermelho (água), passando pelo laranja (solo exposto, ou vegetação rasteira) até o verde escuro (vegetação densa).

Na região onde é encontrado o maior número de depressões fechadas, nota-se uma vegetação menos densa, e mais rasteira em comparação a vegetação no entorno do local das depressões fechadas. No interior das depressões fechadas foi identificado através das imagens de satélite, plantações de café, juntamente com pastagens em grande parte da área. Nenhuma depressão fechada encontra-se em solo exposto, conforme expresso na figura 14.

Das 108 depressões fechadas, a maior parte (70) encontra-se na faixa do índice NVDI 0.479 a 0.663 que representa vegetação média a densa. Estas vegetações, podem estar associados ao plantio de café, sendo que, no processo de mapeamento das depressões fechadas, notou-se que muitas 
plantações ocuparam estas feições e seu interior, seguindo inclusive a orientação do perímetro como orientação de plantio.

Em locais com vegetação densa, representado pelo valor maior que $>0.663$ no índice NVDI foram mapeadas 20 feições, o que se percebe também uma relação com a topografia do local, uma vez que, áreas onde a vegetação é mais densa são locais mais íngremes, e de difícil acesso ou onde não há permissão para plantação de café ou atividades pecuárias.

As demais 18 depressões fechadas encontram-se em áreas de vegetação rasteira e/ou solo exposto, representados pelo índice NVDI com o valor que varia de -0.0739 a 0.11 . Não foi identificada nenhuma depressão fechada como formadora de lagos ou lagoa, todas elas apresentaram o seu interior seco, sem retenção de água no período de análise, conforme pode-se observar no índice $<=0.258 \mathrm{da}$ figura 14 .

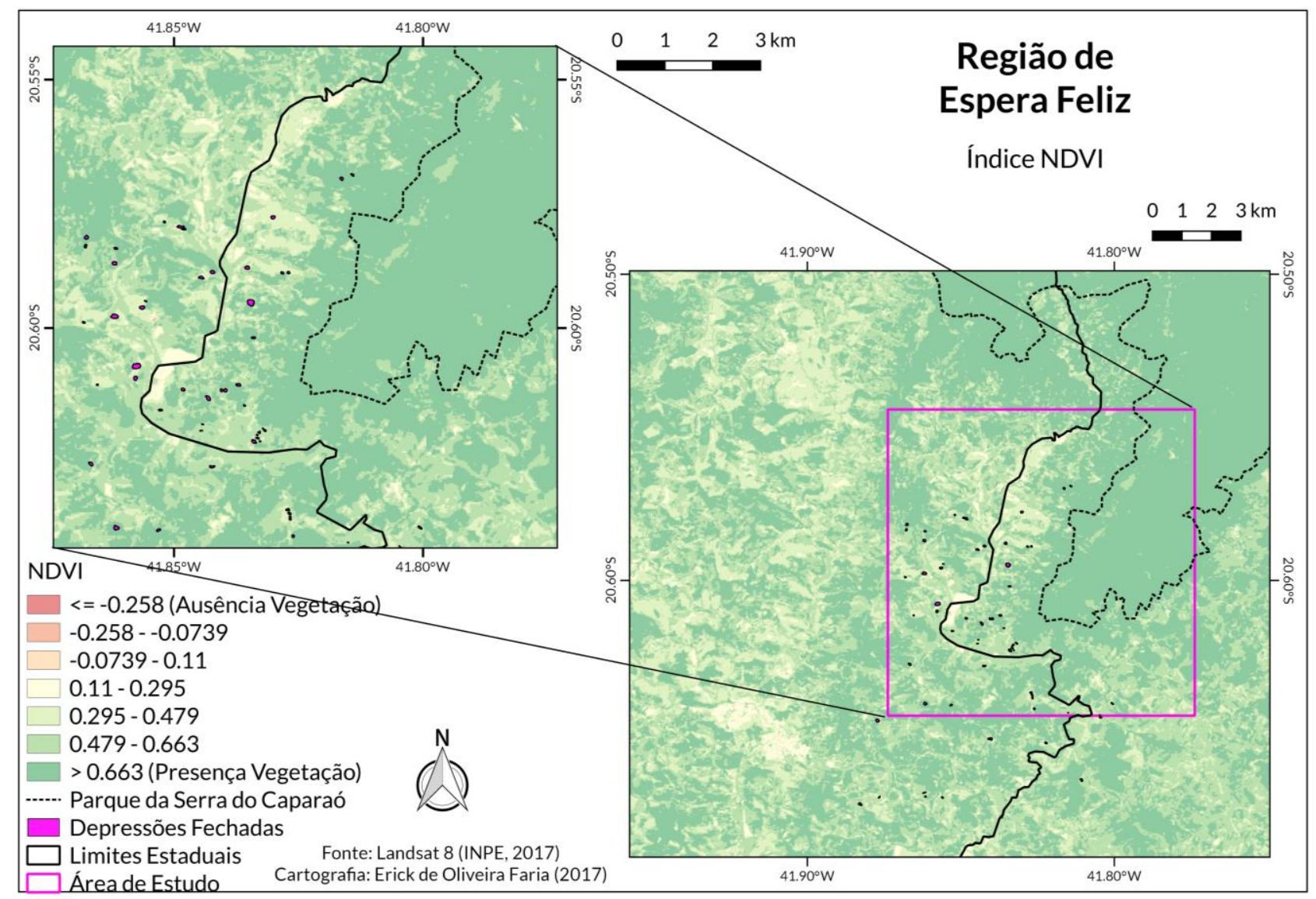

Figura 14 - Mapa da cobertura vegetal e distribuição das depressões fechadas. Fonte: Elaboração própria a partir das bandas do satélite Landsat-8. 


\subsection{O que o contexto na paisagem diz sobre as depressões na região de espera feliz?}

Os resultados das variáveis adotadas para compreender o contexto de ocorrência das depressões na paisagem da Região de Espera Feliz devem ser analisados em conjunto. Cada variável isolada diz sobre seu possível papel na gênese das depressões, mas no conjunto elas retratam o papel/significado dessas feições na paisagem como um todo. Nesses termos, os elementos que melhor expressaram um significado para contribuir com a espacialização dessas feições foram a hipsometria, a declividade e a geologia. A vegetação sugere ser mais uma condição atual da ocupação/transformação da cobertura vegetal que um conjunto fitofisionômico presente no momento de sua formação. Da mesma maneira, a hidrografia, como dito, parece não ter relação com a gênese das feições, mas pode apresentar sinais indiretos de processo que também contribuíram para sua gênese, como tectônica, mudança climática, etc.

Em primeiro lugar, a análise da distribuição das depressões fechadas diante da hipsometria mostra uma concentração em cotas intermediárias do relevo. Em conjunto com a declividade, é possível perceber que elas ocorrem principalmente nas vertentes das colinas e em menor quantidade nos topos. A paisagem apresenta, de maneira geral, três compartimentos: i) escarpas íngremes estruturais ao longo dos esporões controladas pelas estruturas do antiforme do Caparaó, ii) colinas e morros de cotas intermediárias e iii) vales planos de fundo chato colmatados por sedimentos. Nem nos fundos de vales colmatados e nem nas partes mais altas dos esporões elas foram encontradas. Ao contrário, os estudos realizados por Filizola e Boulet, 1995; Coelho Neto, 2003; Uagoda et al., 2006; Alves, 2014 sinalizaram a presença dessas feições, principalmente, em topos planos. Nesses estudos, quando as feições eram encontradas em vertentes, quase sempre estavam rompidas, conectadas com a rede de drenagem.

Da mesma maneira, além da sua posição obedecer a um padrão, quando associamos com a geologia, as depressões evidenciam que se desenvolvem sob coberturas provenientes de rochas graníticas e gnáissicas, sem expressividade em formações recentes nos fundos de vale, como as coberturas quaternárias. Como a predominância do Latossolo ocorre exatamente no domínio das colinas e das rochas gnaissicas, mesmo que os levantamentos pedológicos não sejam detalhados, é possível inferir que as depressões também estejam (como realmente visto) relacionadas a esse tipo de solo. Mateus (2015) já havia mostrado a relação entre Latossolos removidos e a gênese das depressões. Esse estudo apenas reitera suas observações.

Face ao exposto, a distribuição espacial das depressões fechadas na paisagem sugere que tais feições podem sim representar cicatrizes de movimentos de massa (ou outras formas de erosão) como resultado de processos que participam da esculturação do relevo regional. Isso é, feições re- 
presentativas de instabilidade climática e/ou tectônica que afetou a cobertura através do seu rompimento, caracterizando uma típica relação pedogênese / morfogênese, onde a primeira deixa de ser principal e a segunda passa a dominar.

É fato que a região foi profundamente afetada por eventos tectônicos tardios e que eles deixaram estruturas que podem estar influenciando até hoje. Horn (2007), por exemplo, identifica que para a formação dos litotipos, e suas estruturas associadas, foram observados pelo menos cinco momentos, sendo eles: i) formação de um dobramento isoclinal periférico; ii) formação de dobras (apertadas a isoclinais) de grande amplitude; iii) formação de dobras isoclinais e do lineamento de Guaiçui; iv) soerguimento rápido da região após a última fase termal do Evento Brasiliano; v) reativação e/ou neoformação de fraturas junto com intrusão de diques basálticos. A maneira como essas estruturas influenciam está relacionada tanto à esculturação de relevos declivosos quanto à possibilidade de que o manto de alteração seja aprofundado e que, por causa do nível de base, coberturas pedológicas espessas sejam produzidas. Em outras palavras, em paisagens que tiveram movimentos tectônicos em seu contexto geológico, é possível que a forma das vertentes e sua declividade esteja na atualidade influenciando na ocorrência de movimentos de massa, denominados genericamente de deslizamentos (FERNANDES; AMARAL, 1996). Além disso, reativações técnicas em tempos modernos (neotectônica) podem perturbar as plataformas estáveis e movimentar suas coberturas.

Sobre o papel do clima nestes movimentos, o transporte da cobertura ao longo da vertente devido à força gravitacional pode ser intensificado por agentes como a água ou vento (CHORLEY et al., 1984; FERNANDES; AMARAL, 1996). O rompimento do ângulo máximo de repouso da cobertura nas vertentes pode ser uma consequência da saturação dessa pelas águas em eventos de pluviosidade extrema. Da mesma maneira, em climas áridos, com a superfície desprotegida, onde a vegetação que cobre a superfície é rarefeita, chuvas torrenciais podem cumprir o papel de remover a cobertura.

Sobre a gênese das depressões a partir da movimentação da cobertura, deslizamentos podem resultar em cicatrizes, com uma geometria definida, que são formadas, desde a cabeceira, pelo corpo da vertente, estendendo-se até a base onde o material é depositado (ZARUBA; MENCL, 1982; IPT, 1989). É frequente que essas cicatrizes se originem em cabeceiras de drenagem, situadas em declives superiores a $20^{\circ}$, com a formação de um cone de detritos a jusante. Este processo é desenvolvido ao longo dos cursos de drenagem havendo transporte do material erodido e escorregamentos adjacentes a esses canais (terraços, tálus e colúvio) (SESTINI; FLORENZANO; GALLOTTI, 2004). A velocidade do deslocamento e a capacidade de transporte de massas sólidas e liquidas na paisagem tem proporção direta à declividade do relevo. (CHRISTOFOLLETTI, 1980). Como resultado, os valões podem ser entulhados de sedimentos, tornando-se colmatados. A esse respeito, é 
de estanhar que numa área com forte controle estrutura como a estudada, que os vales sejam tão amplos e planos. Haveria uma relação entre a formação das feições nas vertentes e o preenchimento dos vales por sedimentos?

De qualquer maneira, a distribuição espacial das feições sugere uma evolução marcada pela ocorrência de processos modeladores da superfície terrestre, sendo que, no passado, é possível que o desprendimento e transporte de material pedológico tenha deixado, até a atualidade, sinais na forma de depressões fechadas. O que levou ao isolamento em regiões distintas dessas feições, uma vez que as depressões fechadas na região de Espera Feliz são semelhantes às feições reconhecidas por Filizola e Boulet (1995) em outro local, é objeto de novas investigações. Isso porque normalmente cicatrizes de movimentos e massa não são fechadas e expressam de maneira nítida a natureza do deslizamento, se rotacional ou translacional. Aliás, todas as depressões reconhecidas nas imagens são realmente fechadas? São realmente depressões? Eis aí a oportunidade de estudos futuros.

\section{CONSIDERAÇÕES FINAIS}

A região de Espera Feliz é uma região muito estudada, em seus mais diferentes aspectos físicos, devido a sua geolocalização e proximidade com a Serra do Caparaó. O presente estudo buscou contribuir visando o avanço dos trabalhos já feitos na região, uma vez que, a geografia como uma ciência autônoma tem todos os elementos para uma contribuição na análise da evolução da paisagem.

Apesar de não apresentarem um padrão correlacionado a algumas variáveis, como hidrografia e vegetação, as depressões fechadas possuem considerável relação com a condição geomorfológica, ocorrendo em vertentes e morros que constituem compartimentos de altimetria intermediária na paisagem. As depressões fechadas sugerem serem resultados de movimentos de massa ou outras formas de erosão ocorridos na região, representando cicatrizes indicadoras de momentos de instabilidade na relação pedogênese x morfogênese.

Um conjunto distinto de ferramentas desenvolvidos no campo da computação e dos sistemas de gerenciamento de banco de dados propiciou ao sensoriamento remoto que elaborasse métodos de análise espacial e evolução da paisagem. Os dados apresentados no presente trabalho não são a palavra final no que se refere a dinâmica das depressões fechadas, mas, uma proposta auxiliar de análise do tema, uma vez que através da metodologia utilizada obtém-se vários dados com relação a superfície terrestre. 
Os resultados obtidos sinalizam novos questionamentos e demandam que estudos de campo sejam feitos para aferir uma série de apontamentos aqui feitos, baseados, por efeito da proposta deste estudo, apenas através de informações obtidas através do auxílio do sensoriamento remoto.

\section{REFERÊNCIAS}

ALVES, G. B. Estudo da cobertura pedológica e sua relação com a formação e evolução de depressões no Sudoeste de Macaraí (SP). PhD Thesis. Universidade de São Paulo. 2014

AUGUSTO FILHO, O.; WOLLE, C. M. Cartas de risco de escorregamentos: uma proposta metodológica e sua aplicação no município de Ilhabela, SP. São Paulo, 1994.

CASTRO, S. S. O platô de Itapetininga e as formações superficiais, material de origem do Latossolo vermelho escuro orto. Faculdade de Filosofia, Letras e Ciências Humanas, Departamento de Geografia, Universidade de São Paulo, São Paulo, Dissertação de Mestrado, 1980.

CASTRO, S. S.; Netto, A. L C. Evolução Pedogenética em Depressão de Topo na Bacia do Alto Rio Fortaleza, Região do Bananal (RJ). Encontro sobre Engenharia Geotécnica e Hidrologia no Sistema Encosta-Planície Costeira, IV, Anais, Bananal/SP, 2002, 181-192.

CHRISTOFOLETTI, A. Geomorfologia. 2. Ed. São Paulo: Blucher, 1980. 188p.

CHORLEY, R. J.; SCHUMM, S. A.; SUGDEN, D. E. Geomorphology, Methuen. New York, p. 605, 1984.

COELHO NETTO, A. L. Evolução de cabeceiras de drenagem no médio Vale do Rio Paraíba do Sul (SP/RJ): a Formação e o crescimento da Rede de Canais sob Controle Estrutural. Revista Brasileira de Geomorfologia, 2.4: 69-100, 2003.

CRÓSTA, A. P. Caracterização espectral de minerais de Interesse-prospecção mineral e sua utilização em processamento digital de imagens. Simpósio Brasileiro de Sensoriamento Remoto, 7 : 202-209, 1993.

EMPRESA BRASILEIRA DE PESQUISA AGROPECUÁRIA - EMBRAPA. Manual de métodos de análise de solo. Rio de Janeiro, Serviço Nacional de Levantamento e Conservação de Solos, 1979. $247 \mathrm{p}$

FERNANDES, N. F.; AMARAL, C. P. Movimentos de massa: uma abordagem geológicogeomorfológica. Geomorfologia e meio ambiente, v. 5, 1996.

FILIZOLA, H. F.; BOULET, R. Evolution and opening of closed depressions developed in a quartz-kaolinitic sedimentary substratum at Taubaté basin (São Paulo, Brazil), and analogy to the slope evolution. Geomorphology, 16.1: 77-86, 1996. 
FILIZOLA, H. F.; BOULET, R.. Alteração e pedogenese em uma cobertura latossolica vermelhaamarela no medio vale do Rio Paraiba do Sul, bacia de Taubaté-SP. In: Congresso Brasileiro de Ciência do Solo, 25. Viçosa, MG. Resumos expandidos. Viçosa: UFV, 1995

GAO, J.; LO, C. P. Micro-scale modelling of terrain susceptibility to landsliding from a DEM: A GIS approach. Geocarto International, v. 10, n. 4, 1995 p. 15-30, 1995.

HORN, A. H. Geologia da Folha Espera Feliz 1:100.000. Rio de Janeiro, CPRM/UFMG - Programa Geologia do Brasil. 2007

HORN, A. H. Folha Espera Feliz. Programa Geologia Do Brasil (CPRM-Serviço Geológico do Brasil, Rio de Janeiro). 2006

LOPES, L. M. A evolução mineralógica, micromorfológica e geoquímica da bauxita e materiais correlatos da região de Miraí. Universidade São Paulo, São Paulo, Brasil. Dissertação de mestrado, 120p, 1987.

MATEUS, A. C. C. Pedogeomorfologia e evolução da paisagem: gênese de depressões fechadas em vertentes associadas à couraça bauxítica na extremidade sul da Serra do Caparaó, sudeste do Brasil. 2015. 81f. Dissertação (Mestrado em Evolução Crustal e Recursos Naturais) - Escola de Minas, Universidade Federal de Ouro Preto, Ouro Preto, 2015.

NOVO, T. A., NOCE, C. M., PEDROSA-SOARES, A. C., \& BATISTA, G. A. P. Rochas granulíticas da Suíte Caparaó na região do Pico da Bandeira: embasamento oriental do Orógeno Araçuaí. Revista Geonomos, v. 19, n. 2. 2013.

PANQUESTOR, E. K., CARVALHO JÚNIOR, O. A. D., LEAL, L. R., ANDRADE, A. C. D., MARTINS, É. D. S., GUIMARÃES, R. F. Associação do processamento digital de imagens ao uso de parâmetros morfométricos na definição de unidades de paisagem da Bacia do Rio Corrente-BA. Espaço e geografia: geoprocessamento, Brasília, v. 5, n. 1, p. 87-99, 2002.

PEREIRA, M. C.; RODET, J. G. M. A.; SALGADO, A. A. R. Aspectos genéticos e morfológicos das cavidades naturais da Serra da Piedade, Quadrilátero Ferrífero/MG. Revista Brasileira de Geomorfologia, v. 13, n. 4, 2012.

ROCHA, B. M.; SOUZA FILHO, C. R. Geração de bibliotecas espectrais de depósitos de bauxita brasileiros e exemplos de uso para a prospecção de minérios de alumínio por sensoriamento remoto orbital. In: Anais XVI Simpósio Brasileiro de Sensoriamento Remoto - SBSR, Foz do Iguaçu, PR, Brasil, n.16, 2013.

ROSOLEN, V.; HERPIN, U. Expansão dos solos hidromórficos e mudanças na paisagem: um estudo de caso na região Sudeste da Amazônia Brasileira. Acta Amazônica, v. 38, n. 03, p. 483-490, 2008.

ROUSE, J. W.; HAAS, R. H.; SCHELL, J. A.; DEERING, D. W. Monitoring vegetation systems in the Great Plains with ERTS. In: Earth Resources Tecnology Satellite- 1 Symposium, 3, Proceedings. Washington, v.1, Sec. A, p. 309-317, 1973. 
SANTOS, M. S. Manual de fundamentos cartográficos e diretrizes gerais para elaboração de mapas geológicos, geomorfológicos e geotécnicos. In: Publicação IPT. IPT, 1989.

SESTINI, M. F.; FLORENZANO, T. G. Caracterização de cicatrizes de deslizamentos por processamento de dados TM Landsat em Caraguatatuba-SP. Geologia USP. Série Científica, v. 4, n. 2, p. 57-69, 2004.

SILVA, F. S. Distribuição e contexto geológico-geomorfológico das ocorrências de bauxita na região de Espera Feliz, Minas Gerais/Espírito Santo. Dissertação de mestrado em Análise e Modelagem de Sistemas Ambientais, Universidade Federal de Minas Gerais, Minas Gerais, 82 p. 2015.

SOARES, C. C. V. Gênese e evolução mineralógica, micromorfológica e geoquímica da bauxita de Espera Feliz, MG. Dissertação de mestrado em Evolução Crustal e Recursos Naturais, Universidade Federal de Ouro Preto, Minas Gerais, 104 p. 2013.

UAGODA, R.; AVELAR, A.; COELHO NETTO, A. L. Karstic morphology in quartzose rocks: santana river basin at middle paraíba do sul river valley, Minas Gerais state/Brazil. In: Conference Australian and New Zealand Geomorphology Group, 13, Queenstown, Anais, 1: p. 88-88, 2008.

UAGODA, R.; NETTO, A. L. C.; AVELAR, A. S. Morfologia de depressões fechadas em domínio cárstico-quartzítico na bacia do ribeirão santana/mg: datações absolutas iniciais. Revista Brasileira de Geomorfologia-v, v. 10, n. 2, 2009.

UAGODA, R.; AVELAR, A. S.; COELHO NETTO, A. L. Contribuição a geomorfologia cárstica em rochas quartzíticas: médio vale do Rio Preto, RJ/MG. In: VI SIMPÓSIO NACIONAL DE GEOMORFOLOGIA, 2006, Goiânia. Anais do VI Simpósio Nacional de Geomorfologia. Goiânia: UFG, 2006.

UAGODA, R.; AVElAR, A. S.; NETTO, A. L. C. Depressões fechadas em relevo cársticoquartzítico, bacia do Ribeirão Santana, médio vale do rio Paraíba do Sul. Anuário do Instituto de Geociências, v. 29, n. 2, p. 87-100, 2006.

VALERIANO, M. de M. Modelo digital de variáveis morfométricas com dados SRTM para o território nacional: o projeto TOPODATA. In: XII Simpósio Brasileiro de Sensoriamento Remoto. p. $1-8,2005$.

WALSH, S. J.; BUTLER, D. R. Morphometric and multispectral image analysis of debris flows for natural hazard assessment. Geocarto International, v. 12, n. 1, p. 59-70, 1997.

XAVIER, R. A.; NETTO, A. L. C. Ocorrência de depressões fechadas em divisores de drenagem no Médio Vale do Rio Paraíba do Sul. Revista Geografias, v. 4, n. 2, p. 61-68, 2008.

ZARUBA, Q.; MENCL, V. Landslides and their control: development in geotechnical engineering. Amsterdam: Elsevier, 324 p, 1982. 